\title{
ADDITIONAL SASKATCHEWAN SPHINX MOTH RECORDS
}

RONALD R. HOOPER, Box 757, Fort Qu'Appelle, SK SOG 1 S0

Since listing the sphinx moths of Saskatchewan in 1987, a number of interesting discoveries have been made, including two new species for the province. ${ }^{1}$ This brings the present provincial list to 25 species.

Slender Clearwing, Hemaris gracilis (G. \& R.) Figure 1.

On June 14, 1989, I collected one specimen of this species west of lle-àla-Crosse, SK, as a day flier in mixed forest at Labrador Tea (Ledum groenlandicum) blossoms. On June 13, 1992, John Kozial collected two specimens at mile 13 of the Fir River Road northwest of Hudson Bay, SK. This species was previously reported west to Victoria Beach, MB. It is reported to feed on blueberries.

It closely resembles the Hummingbird Clearwing, Hemaris thysbe (Fab.) (see front cover), but the enclosed cell inwards from the middle of the forewing lacks a scaled vein crossing it. There is a reddish-brown line on the underside of the thorax on each side near the bases of the wings. On the underside of each hind wing, there is a yellow patch below the transparent areas.

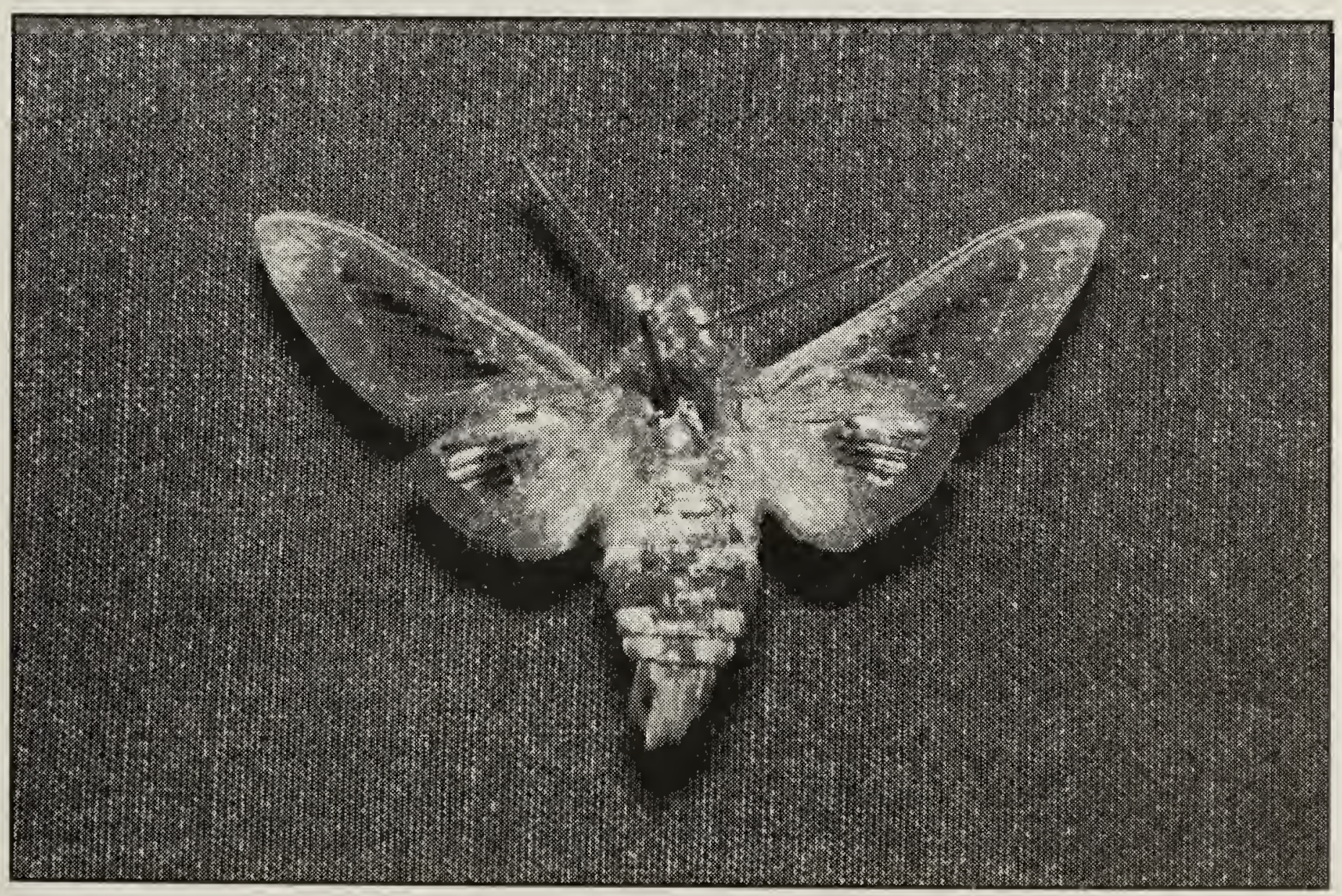

Figure 1. Slender Clearwing collected at lle-à-la-Crosse, SK on 14 June 1989. John Triffo 


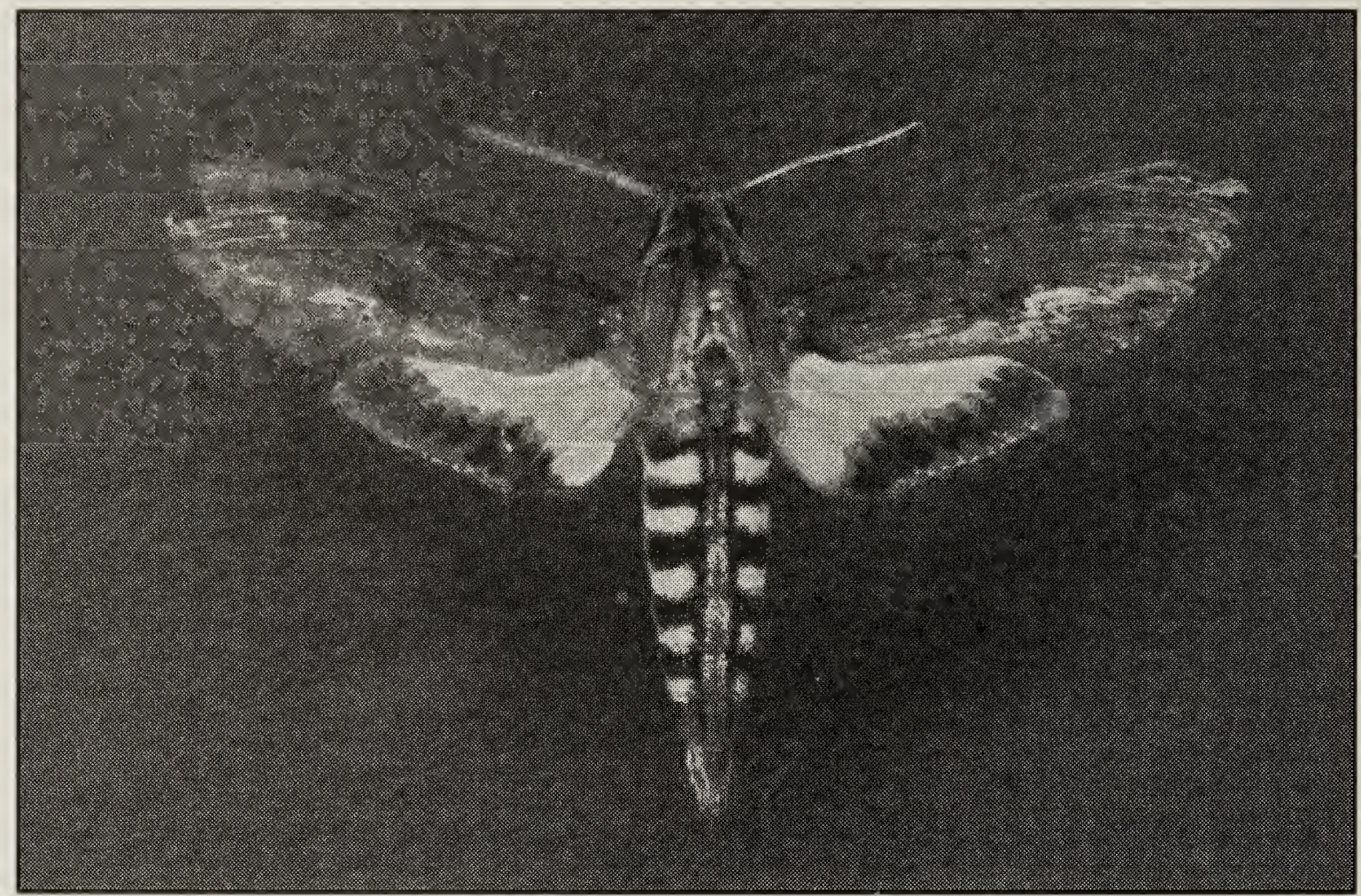

Figure 2. Alope Sphinx, stray in porch, Bjorkdale, SK, 8 August 2000. Wingspan $9.5 \mathrm{~cm}$, body length $5.5 \mathrm{~cm}$.

John Kozial

Alope Sphinx, Erinnyis alope (Drury) Figure 2.

On August 8, 2000, John Kozial from north of Bjorkdale, SK, had a great surprise. He found a specimen of Alope Sphinx roosting on the ceiling of his porch during the daytime. This is the first record of this species for Canada. This tropical species normally ranges north to Arizona and Florida, but it has strayed north to Kansas and New Jersey. Although the Bjorkdale specimen had strayed far, it was in good condition except for signs of wear on the outer edges of the forewings. The moth is blackish-brown on the forewings. The hind wings are yellowish-orange basally and are banded with black outwardly.

This species could probably not produce a brood here as its food plants, Papaya (Carica papaya) and Allamanda (Allamanda spp), do not grow in Canada. Two other species of the genus Erinnyis have strayed north into Ontario.
Gaudy Sphinx, Eumorpha labruscae (L.) Figure 3.

This tropical moth is very rare in the Prairie Provinces. It was collected near Lancer, SK in October, 1934 by D. Micholson. The specimen is at the Canada Agriculture Research Station in Saskatoon. Charles Covell Jr. reports it for Manitoba in A Field Guide to the Moths of Eastern North America.

The Gaudy Sphinx is normally found north to Florida and Texas. From there it sometimes strays northward to Maine, Michigan, Manitoba and Saskatchewan. The food plants are reported to be three members of the grape family, Ampelopsis (Ampelopsis sp.), Cissus (Cissus sp.) and grape (Vitis spp) and a composite, Christmasbush Eupatorium (Eupatorium odoratum). As none of these plants is known in the wild in Saskatchewan, it was assumed that any Saskatchewan specimen would be 


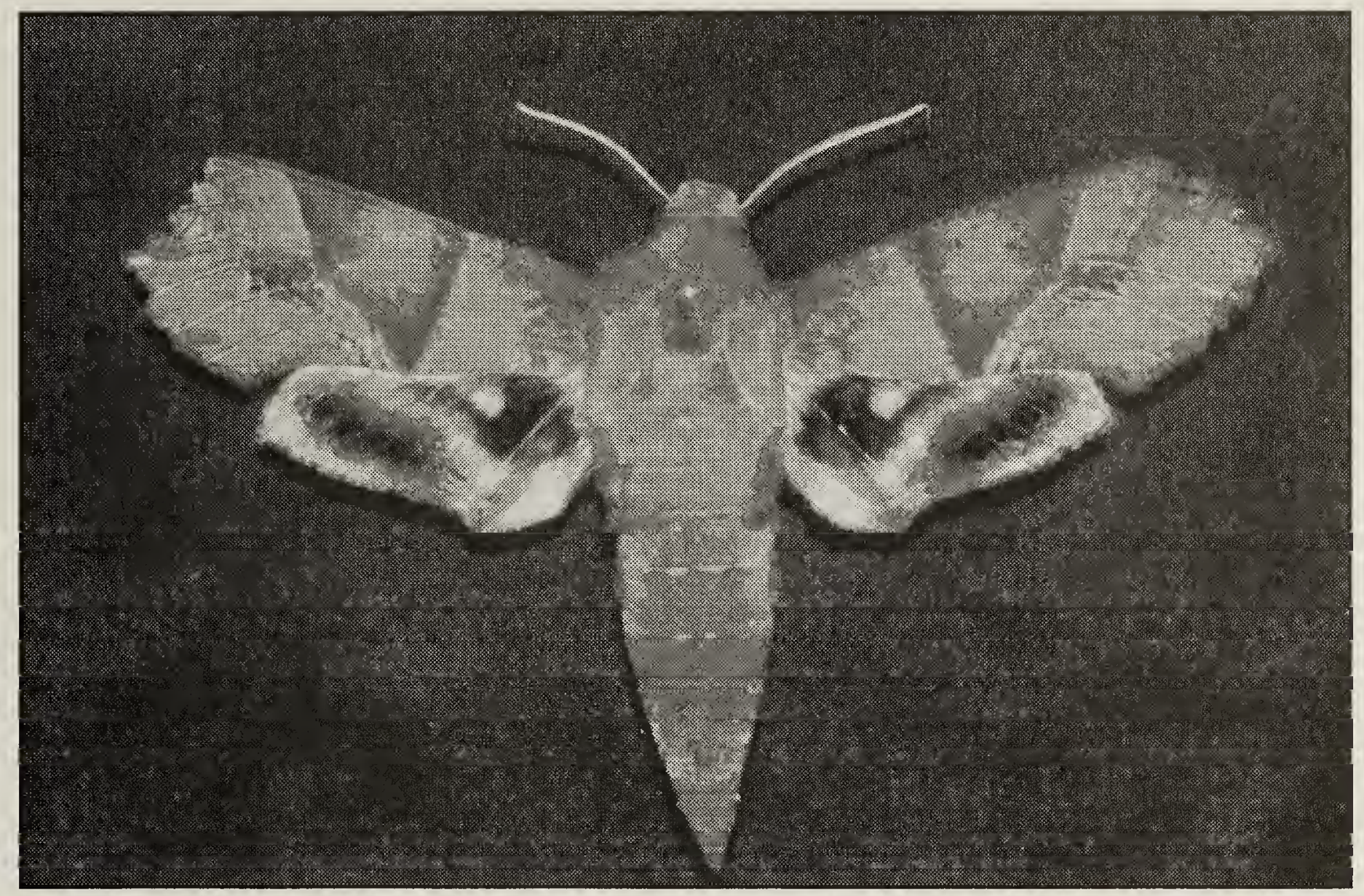

Figure 3. Gaudy Sphinx, emerged 30 October 1999, Regina, SK

John Triffo

a stray and not have developed locally from a caterpillar.

On September 4, 1999, Bill Goodhand found a large, interesting caterpillar (Figure 4) in Regina, SK on planted Virginia Creeper (Parthenocissus species, also in the grape family). It was a combination of shades of brown and cream gray. On the third segment near the front there was a pair of false eyespots. When disturbed, the caterpillar withdrew the first two segments into the third and these eyespots made it look dangerously snake-like. The caterpillar has a slender horn near the rear as Sphinx moth larvae normally have, but during its last instar, this horn is replaced by a round spot with a dark centre. Mr. Goodhand brought the caterpillar to Keith Roney, Curator of Life Sciences at the Royal Saskatchewan Museum, who placed the caterpillar in a jar containing soil. The caterpillar pupated in the soil on
September 18. On October 30, 1999, the adult moth emerged (unfortunately Keith was away and the wing tips were damaged). The adult moth had a greenish-gray body and forewings and purple hindwings with a red line. There was a row of silver spots on each side of the abdomen.

A second Gaudy Sphinx caterpillar was found in the same area but it did not make it through to the adult stage. These specimens prove that Gaudy Sphinx is capable of straying to Canada and producing a brood on Virginia Creeper.

Here are some changes to the previously reported ranges of Saskatchewan sphinx moths.

Laurel Sphinx, Sphinx kalmiae J. E. Smith

This species has now been taken at Indian Head, Crooked Lake, Whitebear Resort (north of Carlyle) and Armit. 


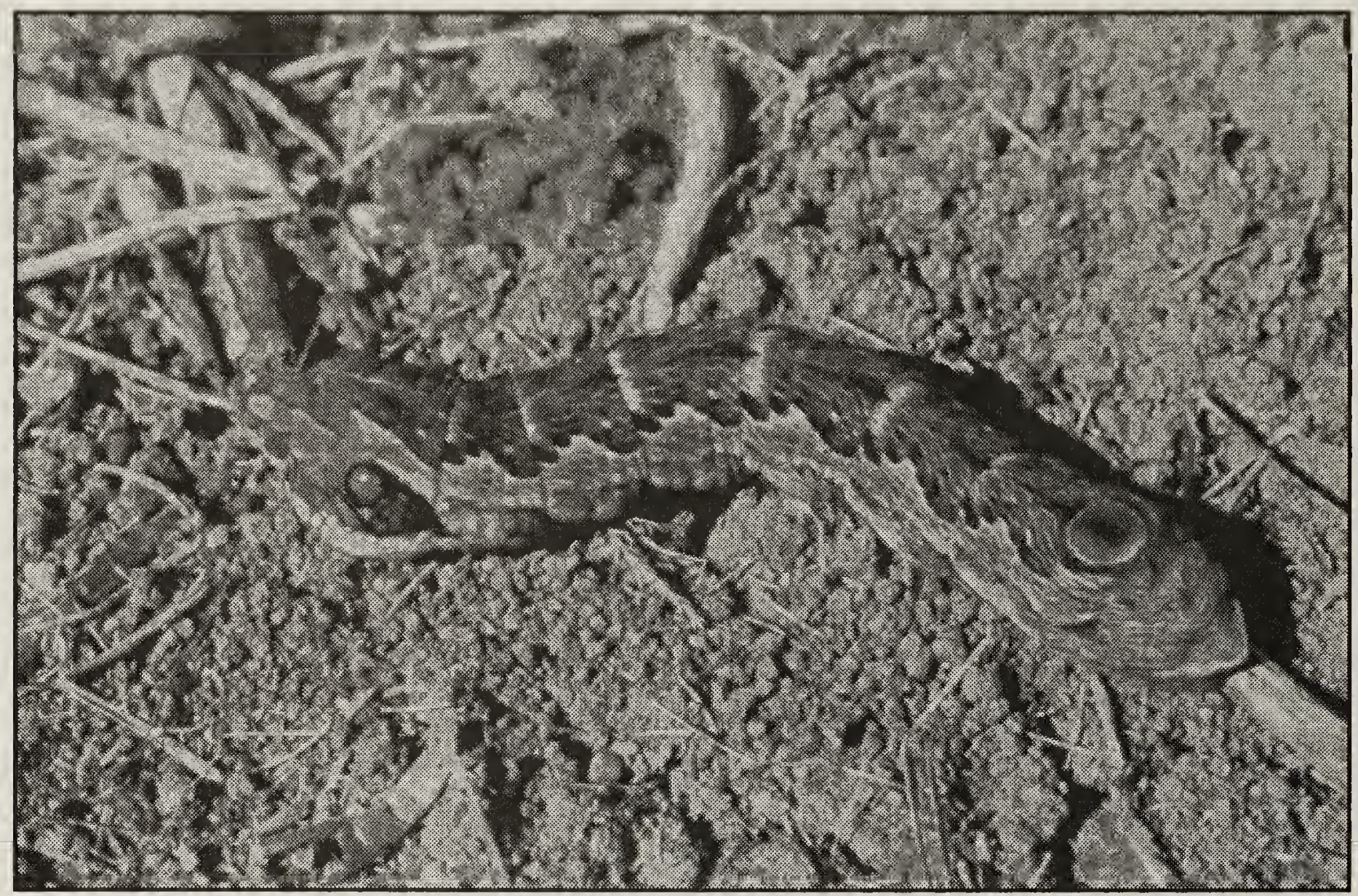

Figure 4. Gaudy Sphinx caterpillar

Keith Roney

Gordian Sphinx, Sphinx gordius Cram. Now known to occur south to Bjorkdale SK (not to Fort Qu'Appelle).

Clemen's Hawkmoth, Sphinx luscitiosa Clem.

Now known to range as far south as Fort Qu'Appelle.

Striped Morning Sphinx, Hyles lineata (F.) (See photograph, p. 174)

Now known to range north to Somme.

Tomato Hornworm, Manduca quinquemaculata (Haw.)

Alvera Galloway found a larva of this species on her tomatoes in Regina on 2 August 2001. She brought it to Keith Roney at the Royal Saskatchewan Museum (RSM). It pupated the next day and the adult emerged on 30 August. This is the first Saskatchewan specimen for the museum.

Spurge Hawkmoth, Hyles euphorbiae (L.)

Renee Sherratt found several caterpillars of this species on Leafy Spurge (Euphorbia esula) at Alta Vista Beach, at the south end of Last Mountain Lake. Two were brought to the RSM on 29 August 2001 and one pupated on 1 September 2001. Since this species was introduced into Saskatchewan to control Leafy Spurge, from 1966 to 1985 , it was not known if it was still extant until this recent find. These individuals could be descendants of the Saskatchewan introductions, or they could have spread here from Alberta, Montana or North Dakota, where they are now established.

1. Hooper, Ronald R. 1987. A check-list of the moths of Saskatchewan. Part 1 Tent caterpillars, silk moths and sphinx moths. Blue Jay 45(3):146 - 152. 